\title{
KEPEMIMPINAN KEPALA MADRASAH DALAM MEMBUDAYAKAN AKHLAKUL KARIMAH SISWA DI MADRASAN ALIYAH NEGERI SAMPANG
}

\author{
Ali Nurhadi, Hasbiyallah Idris, dan Asmoni \\ IAIN Madura, IAIN Madura, dan STKIP PGRI Sumenep \\ Email:www.nurhadibk@gmail.com, hasbiyallah291@gmail.com,dan \\ asmoni@stkippgrisumenep.ac.id
}

\begin{abstract}
Abstrak
Kepemimpinan kepala madrasah merupakan hal penting dalam mengelola madrasah yang dipimpinnya termasuk dalam pembentukan akhlakul karimah. Penelitian ini sebagai penelitian kualitatif dengan jenis deskripstif yang memotret kepemimpinan kepala madrasah dalam membudayakan akhlakul karimah di MAN Sampang. Terdapat tiga fokus penelitian dengan temuan berikut ini. Pertama bentuk pembudayaan akhlakul karimah siswa yang diterapkan di MAN Sampang dilakukan di setiap pagi sebagian guru dan BK menyambut para siswa yang datang, adapun siswa yang memasuki lingkungan MAN Sampang akan bersalaman dengan guru dan guru BK yang menunggu, tidak mendahului guru yang berjalan di depannya, tidak menaiki sepeda motor ketika akan lewat di depan guru dan lobby madrasah, membaca doa sebelum dan sesudah KBM. Kedua kepemimpinan kepala madrasah ikut serta dalam menjalankan kebijakan yang ada diantaranya menjadi contoh dalam pembudayaan akhlak yang baik terhadap para guru dan siswanya. Ketiga faktor pendukung dalam pembudayaan akhlakul karimah di MAN Sampang adanya sarpras yang memadai, kebijakan dari kepala madrasah, kemauan dari diri siswa itu sendiri dan sikap sifat tenaga pendidikan yang secara langsung bertemu dengan peserta didik akan menjadi tauladan bagi para siswa di MAN Sampang.
\end{abstract}

Kata Kunci : Kepemimpinan, kepala madrasah, budaya, akhlakul karimah, siswa.

\begin{abstract}
The leadership of the head of the madrasa is important in managing the madrasa he leads, including the formation of akhlakul karimah. This research is a qualitative research with a descriptive type that portrays the leadership of the madrasa principal in cultivating akhlakul karimah in MAN Sampang. There are three research focuses with the following findings. First, the form of civilizing akhlakul karimah students applied at MAN Sampang is carried out every morning some teachers and BK welcome students who come, while students who enter the MAN Sampang environment will shake hands with the waiting teacher and BK teacher, not precede the teacher who walks in front of him not riding a motorcycle when passing in front of the teacher and madrasa lobby, reading prayers before and after KBM. The two leaderships of the madrasa head participated in carrying out existing policies, including being an example in cultivating good morals towards teachers and students. The three supporting factors in cultivating akhlakul karimah at MAN Sampang are adequate infrastructure, policies from the madrasa principal, the willingness of the students themselves and the attitude of the education staff who directly meet with students will become role models for students at MAN Sampang.
\end{abstract}

Key Words : Leadership, the headmaster, culture, akhlakul karimah, students. 


\section{PENDAHULUAN}

Pendidikan adalah hal yang membedakan antara manusia dengan makhluk lainnya. Akal pikiran manusia yang bisa membuat manusia tersebut menjadi insan yang lebih baik dari pada sebelumnya. Dengan adanya pendidikan akan membuat akal dan pikiran manusia menjadi lebih berfungsi dengan baik. Secara umum pendidikan identik dengan lembaga pendidikan, namun perlu kita ketahui bahwasanya dengan adanya alam semesta ini kita bisa memperoleh nilai-nilai pendidikan. Secara umum pendidikan lebih dikenal dan dicirikan dengan adanya lembaga pendidikan.

Terdapat lembaga pendidikan yang banyak kita jumpai di era milenial ini. Lembaga-lembaga pendidikan pada saat ini sangatlah gampang ditemuakan dibandingkan di era sebelumnya, yang mana seseorang sulit mengenyah pendidikan di lembaga pendidikan yang formal. Terdapat dua lembaga pendidikan yaitu berbasis islam seperti MI, MTS, MA dan lembaga yang berbasis bukan keislaman seperti SD, SMP dan SMA.

Sebagian besar peminat dikalangan masyarakat kota ataupun pedesaan yang mana adalah lembaga pendidikan formal yang seharusnya ditata dengan baik serta di berdayakan sehingga dapat mengembangkan lembaga sebagai pusat pengkajian suatu ilmu yang berkaitan keislaman yang lebih dinamis dan berkembang dikalangan masyarakat dan memberdayakan masyarakat melalui pemimpin visioner, serta menjadikan semua anggota organisasi dilembaga pendidikan tersebut sebagai bagian dari leadership dan menjadikan lembaga organisasi sebagai pusat belajar. Hal ini adalah salah satu fungsi dari kepemimpinan kepala madrasah dimana seorang kepala madrasah harus bisa menjadi motor penggerak penentu arah kebijakan menuju keberhasilah sekolah dan pendidikan secara luas. ${ }^{1}$

Dengan demikian dapat dipahami bahwa seorang kepala madrasah selaku pemimpin dari organisai tersebut haruslah memiliki tata cara atau pemikiran yang bisa dijadikan tindakan kedepannya demi kemajuan dan perkembangan dari organisasi tersebut kedepannya.dimana dalam hal tersebut mengacu pada visi dan misi yang sudah dirancang dan ditetapkan oleh semua anggota masyarakat khususnya tenaga pendidik dan kependidikan di lembaga tersebut yang hal ini dipimpin langsung oleh kepala madrasah. Oleh karena itu kemajuan dan perkembangan sekolah tersebut tidak lepas dari peran pemimpin yang bisa memimpin suatu lembaga pendidikan tersebut dengan baik sesuau dengan visi dan misi yang sudah disepakati dan ditetapkan.

Perilaku kepala madrasah sebagai pemimpin sekaligus pembuat kebijakan yang nantinya akan diterapkan demi keberlangsungan suatu lembaga pendidikan yang dipimpinnya berimplikasi pada kinerja bawahannya suatu pendidik dan tenaga kependidikan. seorang kepala madrasah harus bisa memimpin dengan baik yang nantinya akan memberikan jalan keluar terhadap problem yang akan terjadi pada lembaga yang dipimpinnya, utamanya permaslahan yang berkaitan dengan proses pembelajaran. Oleh karena itu selain menjadi pemimpin lembaga pendidikan seorang kepala madrasah harus bisa menjadi panutan terhadap bawahannya, seorang pemimpin harus bisa memimpin dengan baik sebagaimana strategi kepemimpinan yang sudah diterapkan oleh tokoh-tokoh Islam.

\footnotetext{
${ }^{1}$ Djafri Nivianty, Manajemen Kepemimpinan Kepala Sekolah (Yogyakarta: CV Budi Utama, 2012), 4.
} 
Kepemimpinan adalah perihal memimpin atau cara memimpin. ${ }^{2}$ Dapat dipahami bahwasanya cara memimpin adalah suatu proses dimana seorang pemimpin menggunakan kekuasaannya untuk mengelola dengan cara mempengaruhi bawahannya untuk ikut serta dalam kepemimpinannya. Perbedaan antara satu organisasi dengan organisasi lain khususnya secara internal, dibentuk oleh pimpinan beserta anggota organisasi dalam mencapai tujuannya, begitu juga dengan adanya pergantian pimpinan, akan mempengaruhi budaya suatu organisasi. ${ }^{3}$

Seorang pemimpin madrasah haruslah bisa memberikan ketertarikan terhadap para bawahannya. Karena pada dasarnya seorang pemimpin madrasah merupakan yang bisa menentukan suatu keberhasilah lembaga pendidikan tersebut. Setiap kebijakan yang akan terapkan haruslah dipertimbangkan dengan sebaik-baiknya. Dimana, ketika pemimpin dapat memberikan dan menanamkan nilai-nilai positif maka timbal baliknya adalah positif juga bagi masyarakat sekolah yang dipimpinnya seperti halnya budaya religius.

Budaya religius merupakan salah satu budaya yang dijadikan unggulan oleh lembaga pendidikan sebagai penunjang keberhasilan atau salah satu ciri khas dalam sebuah lembaga pendidikan. Budaya religius misalnya, banyak lembaga pendidikan yang sudah mengembangkan dan mengakarkan budaya religius di lembaga pendidikannnya khususnya oleh seorang kepala madrsah selaku pemimpin dari lembaga pendidikan tersebut.

Terciptanya suasana religius di suatu lembaga pendidikan itu dapat dilihat dari perilaku positif dari warga madrasah seperti halnya pergaulan dari siswa, bagaimana pakaian seragam yang dikenakan oleh siswa, bagaimana keadaan di lingkungan madrasah tersebut, bagaimana suatu lembaga membuat program praktik ibadah bagi siswa dan sikap postif lainnya. Sehingga, siswa bisa berperilaku religius dan memiliki akhlak yang baik.

Budaya madrasah merupakan seperangkat yang sengaja diciptakan dari berbagai nilai yang dijadikan pegangan oleh kepala madrasah sebagai pemimpin lembaga pendidikan yang nantinya dijadikan teladan oleh para guru dan tenaga kependidikan yang berada dilingkungan lembaga madrasah tersebut.

Lulusan pendidikan yang pada saat ini menjadi pusat perhatian oleh masyarakat luar, sudah mejadi keharusan terhadap lulusan lembaga pendidikan mempunya etika dan moral yang bagus. Terkadang ada lulusan lembaga pendidikan yang sikapnya kurang baik. Hal ini disebabkan salah satunya yaitu dilingkungan mardrasah yang kurang diperhatikan sehingga menghasilkan lulusan yang seperti ini. Berbagai perubahan seperti perubahan budaya mulai dari gaya hidup, prilaku dan lain sebagainya. Banyak ditemukan di sebuat koran, majalah, stasiun televisi yang menayangkan tawuran antar pelajar, ditangkap karea mengonsumsi minuman yang dilarang dan tindakan amoral lainnya yang mana dalam hal ini salah satu atu penyebabnya yaitu lingkungan madrasah yang kurang baik serta didikan yang kurang tegas. Dalam hal ini gurulah yang harus menjadi panutan oleh para siswanya. Tindakan atau prilaku yang baik akan

\footnotetext{
${ }^{2}$ Helmawati, Meningkatkan Kinerja Kepala Sekolah/Madrasah Melalui Managerial Skills (Jakarta: PT Asdi Mahasatya, 2014), 34.

${ }^{3}$ Ester Manik and Kamal Bustomi, "Pengaruh Kepemimpinan Kepala Sekolah, Budaya Organisasi Dan Motivasi Kerja Terhadap Kinerja Guru Pada SMP Negeri 3 Rancaekek," Urnal Ekonomi, Bisnis \& Entrepreneurship 5, no. 2 (2011): 99.
} 
mencerminkan kepribadian guru tersebut oleh karena itu pembinaan dan bimbingan yang baik harus diterapkan dilingkungan madrasah.

Dari berbagai kasus yang terjadi apabila tidak ditindak lanjuti hal ini akan memberikan dampak terhadap masa depan bangsa yang mana jika kenakalan remaja ini semakin marak terjadi dan guru kurang memperhatikan hal terebut maka hal ini akan memberikan pengaruh yang buruk terhadap jalanya suatu pendidikan sehingga hal ini akan mencoreng nama baik dari pendidikan tersebut. Maka dari itu budaya yang berakar dari budaya religius perlu diperhatikan, dikembangkan dan dipraktekkan di lingkungan madrasah. Alangkah baiknya budaya ini diterapkan sama rata terhadap masyarakat di madrasah.

Maka penting sekali di dalam suatu organisasi sekolah untuk menciptakan budaya religius guna memberikan nilai-nilai dan kepribadian yang baik pada diri peserta didik sebagai pembiasaan. Sehingga, peserta didik terbiasa untuk selalu bersikap religius dimanapun ia berada. Selain itu, nilai-nilai religius juga ditanamkan pada diri peserta didik pada saat proses pembelajaran di dalam kelas sedang berlangsung agar mereka terbiasa dan dapat menerapkannya dimana pun ia berada. Pada dasarnya organisasi merupakan sistem nilai yang diyakini dan dapat dipelajari, dapat diterapkan dan dikembangkan secara terus menerus. ${ }^{4}$

Dapat dipahami bahwasanya budaya religius ini selain memberikan kepribadian yang baik terhadap seseorang juga membuat seseorang tersebut memiliki prinsip yang baik pada masa hidupnya. Dari berbagai macam budaya religius yang perlu ditekankan untuk diterapkan yaitu pengembangan budaya akhlakul karimah.

Pengembangan budaya berakhlakul karimah ini perlu diperhatikaj dengan baik. Disetiap lembaga pendidikan pasti menerapkan budaya ini lebih-lebih di lingkugan sekolah yang notabeninya berbasis islam seperti Madrasah Ibtidaiyah, Madrasah Tsanawiyah, Madrasah Aliyah dan lembaga pendidikan lainnya.

Akhlak menurut Mohammad Muchlis Solichin adalah sifat yang tertanam dalam jiwa yang menimbulkan berbagai jenis perbuatan dengan gampang dan mudah dengan tidak membutuhkan pertimbangan dan perenungan. Sementara menurut. ${ }^{5}$ Sedangkan menurut Ibrahim Bafadhol akhlak adalah ikhtiar atau usaha manusia dewasa untuk mengarahkan peserta didik agar menjadi manusia yanng bertaqwa kepada Allah Ta'ala. ${ }^{6}$

Berdasarkan beberapa pendapat di atas dapat dipahami bahwasanya akhlak merupakan suatu usaha manusia yang berawal daripendidikan yang nantinya menjadi akar dalam diri seseorang yang pada akhirnya akan reflek berbentuk perbuatan tanpa disengaja untuk dilakukan.

Berbagai bentuk dan ruang lingkup akhlak islami yang demikian iti dapat dipaparkan sebagai berikut:a) akhlak terhadap Allah, seperti bertaqwa kepadanya, sabar dalam menjalani hidup, menjalankan perintahnya, bersyukur terhadap nikmat yang didapatkannya. b) akhlak terhadap sesama manusia yaitu: akhlak terhadap diri sendiri seperti jujur, optimis, hemat dan lain sebagainya. Akhlak terhadap bapak atau ibu guru

\footnotetext{
${ }^{4}$ Saefullah, Manajemen Pendidikan Islam (Bandung: CV. Pustaka Setia, 2019), 95.

${ }^{5}$ Mohammad Muchlis Solichin, Akhlaq Dan Tasawuf Dalam Wacana Kontenporer (Surabaya: CV Salsabila Putra Pratama, 2014), 22.

6 Ibrahim Bafadhol, "Pendidikan Akhlak Dalam Persfektif Islam," Jurnal Edukasi Islami Jurnal Pendidikan Islam 06, no. 12 (2017): 46.
} 
seperti berbakti terhadap bapak/ibu guru, hormat dan lain sebagainya, c) akhlak terhadap orang lain seperti berkata jujur, memaafkan orang lain dan sebagainya. d) akhlak terhadap lingkungan seperti menjaga kebersihan kelas, menjaga tanaman dan tidak merusaknya dan lain senbagainya.

Dengan demikian dapat dipahami bahwasanya peranan akhlak disini sangatlah penting terhadap keberlangsungan hidup baik itu di dalam lingkungan sekolah maupun nlingkungan masyarakat umum. Sikap menghargai, menghormati dan menjaga prilaku terhadap sesama manusia sangatlah dibutuhkan demi simbiosis mutualismenya. Begitupun akhlak kita terhadap yang lainnya seperti menjaga lingkungan hidup, kebersihan kelas dan lingkungan madrasah. Jika setiap masyarakat yang ada dimadrasah menerapkan akhlak yang baik terhadap lingkungan madrasah maka yang keharmonisan suasana madrasah tersebut akan terjaga dengan baik, lingkungan akan terawat, jalinan silaturrahim akan terjaga dan lain sebagainya. maka dari itu hal ini juga menjadi pertimbangan terhadap kinerja kepala madrasah hunungan masyarakat seperti masyarakat madani.

Pada dasarnya akhlak yang baik ini terhadap madrasah akan sangat berperan penting. Maju tidaknya suatu madrasah tergantung pada akhlak masyarakat madrasah itu sendiri. seseorang yang berakhlak mulia akan. selalu melaksanakan kewajiban yang diperintahkan oleh Allah SWT, termasuk menjaga kerukunan antar sesama manusia dilingkungan lembaga pendidikan.

Kerukunan disini juga menjadi salah satu tujuan diterapkan dan dikembangkannya suatu akhlak didalam lembaga pendidikan. Kerukunan terhadap sesama manusia di lingkungan pendidikan merupakan suatu akhlak yang baik dan bisa juga disebut akhlakul karimah.

Maka melalui budaya akhlakul karimah ini lembaga pendidikan akan semakin mempunyai ciri khas kelembagaan yang nantinya bisa dijadikan daya tarik tersendiri terhadap masyarakat luar sehinnga mereka mempunya ambisi untuk menyekolahka anaknya ke lembaga tersebut.

Dengan demikian pengembangan budaya akhlakul karimah ini sangat bagus diterapkan melihat lingkungan dan keadaan pendidikan moral anak bangsa pada saat ini merosot dan sangat memprihatinkan.

Dalam penelitian ini peneliti memfokuskan pada 3 pokok permasalahan saja, yaitu: Pertama, pembudayaan akhlakul karimah siswa apa saja yang diterapkan di MAN Sampang. Kedua, bagaimana peran kepala madrasah dalam membudayakan akhlakul karimah siswa di MAN Sampang. Ketiga, faktor apa saja yang mendukung dalam pembudayaan akhlakul karimah siswa di MAN Sampang.

Dan tujuan dari penelitian ini yaitu untuk mendeksripsikan seluruh rumusan masalah yang ada di penelitian ini yaitu: Pertama, untuk mendeskripsikan pembudayaan akhlakul karimah siswa apa saja yang diterapkan di MAN Sampang. Kedua, untuk mendeskripsikan bagaimana peran kepala madrasah dalam membudayakan akhlakul karimah siswa di MAN Sampang. Ketiga, untuk mendeskripsikan faktor apa saja yang mendukung dalam pembudayaan akhlakul karimah siswa di MAN Sampang. Harapan peneliti terhadap hasil penelitian ini nantinya akan bermanfaat dan menjadi referensi bagi para pembaca khususnya dalam membudayakan akhlakul karimah siswa. 


\section{METODE PENELITIAN}

Dalam penelitian ini jenis pendekatan yang digunakan oleh peneliti adalah pendekatan penelitian kualitatif secara deskriptif. Artinya peneliti mendeskripsikan yang terjadi di lapangan secara alamiah. Di samping itu permasalahan yang ada secara umum dialami oleh beberapa madrasah baik negeri maupun swasta sehingga jenis penelitian ini deskriptif. Untuk sumber data dalam penelitian ini, peneliti mengambil 2 sumber, yaitu primer dan sekunder Untuk sumber data primer yaitu mengambil sumber data kepala madrasah, guru dan siswa, sedangkan untuk sumber data sekunder yaitu berupa data yang telah lebih dahulu dikumpulkan dan dilaporkan oleh orang atau instansi di luar dari peneliti sendiri seperti majalah, dokumentasi dan lain sebagainya.

Untuk prosedur pengumpulan data dalam penelitian ini yaitu ada 3 yaitu observasi, wawancara dan dokumentasi. Dalam prosedur pengumpulan data observasi, maka peneliti menggunakan observasi nonpartisipan yaitu dimana kehadiran peneliti disini hanya sebagai peneliti dan tidak ikut serta dalam kegiatan didalamnya. Alasan menggunakan observasi nonpartisipan yaitu karena peneliti disini hanya meneliti prilaku siswa serta bagaimana masyarakat membudayakan akhlakul karimah terhadap siswa. Peneliti juga bukan bagian dari madrasah ini baik sebagai guru, tenaga kependidikan atau komponen langsung madrasah. Sedangkan untuk prosedur pengumpulan data teknik wawancara, peneliti menggunakan wawancara semi terstruktur yaitu gabungan model terstruktur dan tidak terstruktur dimana hal ini tidak terpaku pada teks pertanyaan dan mendapatkan informasi yang luas, alasan penliti memilih wawancara semi terstruktur ini karena akan mendapatkan jawaban dari interview yang sangat luas dan bervariasi. Dan untuk pengumpulan data selanjutnya yaitu dokumentasi, dalam penelitian ini peneliti menggunakan dokumentasi berupa rekaman, foto-foto selama proses penelitian berlangsung.

Sedangkan untuk teknik analisis datanya, peneliti menggunakan 3 teknik yaitu konsolidasi data yang artinya menggabungkan beberapa jenis data, misalnya data hasil wawancara dari siswa dan guru digabungkan untuk melihat perilaku siswa, yang kedua yaitu penyajian data dan ketiga yaitu penarikan kesimpulan dan verifikasi data. Adapun model analis data yang digunakan meliputi kondensasi, display data dan veryvikasi atau penarikan kesimpulan.

\section{HASIL DAN PEMBAHASAN}

\section{Bentuk Budaya Akhlakul Karimah Siswa yang Diterapkan di MAN Sampang}

Salah satu budaya yang dilakukan di lingkungan MAN sampang adalah budaya akhlakul karimah. Hal ini bukanlah hal baru bagi masyarakat MAN Sampang yang mana dalam hal ini mengacu pada visi MAN Sampang itu sendiri yaitu berakhlakul karimah dan unggul dalam prestasi.

Untuk membangun hal tersebut maka perlu adanya suatu pembiasaan karena salah satu terbentuknya akhlakul karimah yaitu dari sebuah pembiasaan ${ }^{7}$ pembiasaan ini bisa diciptakan dengan peraturan dan kebijakan dari kepala madrasah sehingga bisa diterapka oleh masyarakat yang ada di MAN Sampang itu sendiri khususnya para siswa.

\footnotetext{
${ }^{7}$ M. Imam Pamungkas, “Akhlak Muslim Modern: Membangun Karakter Generasi Bangsa,” Marja, 2016, 42.
} 
Berdasarkan hasil temuan saya di MAN Sampang, terdapat beberapa budaya akhlakul karimah baik itu dalam mencari ilmu, sesama manusia dan terhadap alam/lingkungan sekitar halaman MAN Sampang. Ada berbagai pembudayaan akhlakul karimah yang diterapkan di MAN Sampang diantaranya yaitu penerapan 3s (senyum, sapa, salam), hormat terhadap yang lebih tua, menunduk ketikan akan berjalan di depan guru, membaca doa sebelum dan sesudah kegiatan belajar mengajar, bersih-bersih tiap hari jum'at, turun dari kendaraan yang di kendarai ketika lewat didepan giuru yang menyambut para siswa disaat pagi. Selain itu budaya yang diterapkan di MAN Sampang yaitu sebelum bel masuk tepatnya di pagi hari MAN Sampang selalu melantunkan ayat al-Qur'an dan pihak BK dan tim tatib bersiap di pintu gerbang menyambut siswa yang datang dengan tujuan agar mereka ketika masuk ke madrasah tidak seenaknya masuk, artinya ketika ada guru-guru di depan gerbang mereka langsung turun dari sepedanya dan bersalaman dengan guru-guru tersebut serta pihak BK dan tim TATIB mengontrol kelengkapan dari siswa tersebut.

Setelah itu ketika ada siswa yang datang terlambat, maka guru tidak mempersilahkan bagi siswa tersebut untuk masuk melainkan memberikan mereka sanksi berupa pembacaan al-Qur'an 1 juz atau yasiin. Itu dilakukan agar selain siswa memiliki efek jera juga mereka mendapatkan pahala dengan membaca al-Qur'an dan hal tersebut bisa dijadikan pembiasaan mereka untuk membaca al-Qur'an dan yasiin. Selain itu masih banyak lagi penerapan budaya akhlakul karimah yang ada di MAN Sampang.

Berkenaan dengan hasil penelitian diatas, maka kaitannya dengan teori yang dibahas pada subbab sebelumnya yaitu menurut J.J. Hoenigman yang dikutib oleh U. Saefullah menyatakan budaya dibedakan menjadi tiga, yaitu gagasan, aktivitas, dan artefak. ${ }^{8}$ Ketiga budaya tersebut dapat dijelaskan bahwa gagasan merupakan ide, nilai, aturan, norma, dan pemikiran masyarakat sekolah tentang budaya yang diterapkan di lingkup madrasah tersebut.

Kemudian aktivitas merupakan tindakan warga madarasah dalam melaksanakan budaya akhlakul karimah yang diterapkan di madarasah tersebut. Artinya semua warga madrasah berperilaku sesuai dengan aturan yang ditetapkan dalam budaya akhlakul karimah tersebut. Sedangkan artefak disini dapat disebut dengan karya atau hasil dari aktivitas yang dilakukan oleh warga sekolah mengenai penerapan budaya akhlakul karimah di suatu lembaga pendidikan.

Ada beberapa bentuk yang dapat dilakukan dalam pembentukan nilai-nilai akhlakul karimah siswa, yaitu sebagai berikut: ${ }^{9}$

Pertama Senyum, Sapa, Salam (3S). Senyum, sapa dan salam dalam perspektif menunjukkan bahwa komunitas masyarakat memiliki kedamaian, santun, saling tenggang rasa, toleran dan rasa hormat. Sebab itu, senyum, salam dan sapa harus dibudayakan pada semua komunitas, baik keluarga, sekolah atau masyarakat sehingga cerminan bangsa Indonesia sebagai bangsa yang santun, damai, toleran dan

\footnotetext{
${ }^{8}$ Saefullah, Manajemen Pendidikan Islam, 89-90.

${ }^{9}$ Asmaun Sahlan, Mewujudkan Budaya Religius Di Sekolah Upaya Mengembangkan PAI Dari Teori Ke Aksi (Malang: UIN Maliki Press, 2010), 117-21.
} 
hormat muncul kembali.dalam hal ini bukan hanya siswa namun pendidikpun juga harus menerapkan. ${ }^{10}$

Kedua saling hormat. Budaya saling menhormati antara yang muda dengan yang lebih tua, menghormati perbedaan pemahaman agama, didala ajaran agama islam hal seperti ini sangatlah dianjurkan melihat banyak perbedaan dan prilaku indihidu yang bisa menciptakan perpecahan. Sikap saling menghormati kepada yang lebih tua juga juga diterapkan di lingkungan MAN Sampang hal ini dilakukan sebagai bentuk contoh budaya yang baik terhadap para siswa di MAN sampang sehingga dengan praktik tersebut bisa menjadi teladan yang baik.

Ketiga doa bersama sebelum dan sesudah proses KBM. Istighasah adalah doa bersama yang bertujuan memohon pertolongan dari Allah SWT. inti dari kegiatan ini sebenarnya dhikrullah dalam rangka taqarrub ila Allah (mendekatkan diri kepada Allah Allah SWT).

Keempat tidak mendahului guru yang sedang berjalan di depannya. Budaya seperti ini merupakan budaya yang baik untuk dilakukan, tidak mendahului guru yang sedang berjalan di depannya merupakan suatu prilaku yang baik. Dengan ini siswa menunjukkan sikap prilaku yang baik terhadap guru tersebut.

Kelima berdoa sebelum dan setelah melakukan kegiatan belajar mengajar Bukan hanya budaya akhlakul karimah terhadap sesama manusia saja yang diterapkan di lingkungan MAN Sampang, budaya sebelum dan sesudah mencari ilmu juga diterapkan, yang mana dalam hal ini para siswa dan guru yang akan memulai pelajaran akan membaca doa memulai pelajaran dan ketika akan mengakhiri juga membaca doa akhir majlis. Hal ini merupakan suatu prilaku yang sudah menjadi kebiasaan di MAN Sampang.

Keenam menjaga kebersihan lingkungan. Budaya akhlakul karimah terhadap lingkungan juga diterapkan di MAN Sampang, tak heran didinding depan kelas ada banner yang berisikan kebersihan sebagian dari iman. Di setiap depan kelas terdapat tong sampang yang bertuliskan jagalah kebersihan, hal ini sudah menjadi kebudayaan yang baik di lingkungan MAN Sampang. Man sampang adalah madrasah adiwiyata yang juga menjaga kebersihan dan keindahan lingkungannya. Terdapat taman-taman yang bagus sehinnga membuat masyarakat yang ada di MAN Sampang tersebut bisa senang dan nyaman.

Ketujuh menunduk ketika berjalan di depan guru. Siswa yang akan lewat di depan guru yang sedang duduk atau berdiri akan menunduk. Hal ini adalah sebagai bentuk rasa takdim terhadap guru tersebut. Prilaku ini sudah menjadi sebuah kebiasaan di lingkungan MAN Sampang.

Pada dasarnya strategi pembiasaan menjadi hal yang paling efektif dalam menumbuhkan akhlakul karimah siswa. Hal ini sebagaimana diungkapkan Nurhadi yang menyatakan strategi pembiasaan yang digunakan itu dengan menghidupkan kegiatan-kegiatan positif keagamaan, seperti sholat berjamaah, membaca surat-surat

10 Miftahul Alimin and Muzammil Muzammil, "Keteladanan Guru Dalam Menanamkan Nilai-Nilai Keagamaan Sebagai Upaya Pembinaan Akhlakul Karimah Siswa," Edukais: Jurnal Pemikiran Keislaman 4, no. 1 (2020): 48, https://doi.org/10.36835/edukais.2020.4.1.43-54. 
pendek Al-Qur'an dan surat Yasin sebelum pembelajaran, membaca doa sebelum dan sesudah pembelajaran, dan mencium tangan guru ${ }^{11}$

Berfasarkan hal tersebut pembiasaan dilakukan untuk menumbuhkan budaya. Pembiasaan yang kuat pada kegiatan siswa yang positif akan menjadi budaya dan diterapkan dalam kehidupan sehari-harinya.

\section{Kepemimpinan Kepala Madrasah dalam Membudayakan Akhlakul Karimah Siswa di MAN Sampang}

Peran kepala Madrasah dalam sebuah lembaga pendidikan menjadi pengaruh penting dalam terlaksananya program yang telah ditetapkan oleh madrasah. Dimana program tersebut merupakan hasil keputusan dari kepala smadrasah untuk menciptakan madrasah yang lebih maju.

Dalam hal ini peran kepala madrasah di MAN Sampang dalam penerapan budaya akhlakul karimah yaitu tidak hanya berperan sebagai pendidik, melainkan beliau memberikan contoh langsung kepada peserta didiknya untuk bagaimana bersikap baik dan sopan. Hal ini juga dijelaskan oleh Ali Maulida yang menjelaskan bahwasanya kepala madrasah selaku pemimpin tertinggi di sebuah madrasah akan menjadi figur yang banyak dicontoh oleh bawahannya, hal ini akan menjadi teladan baik apabila prilaku seorang kepala madrasah tersebut beik juga. ${ }^{12}$

Di MAN Sampang kepala madrasahnya sering melakukan pengontrolan terhadap keadaan peserta didiknya ke tiap-tiap kelas agar beliau dapat melihat sendiri bagaimana perkembangan dari peserta didiknya itu sendiri. Setelah itu ketika ada salah satu peserta didiknya yang melanggar beliau selalu memberikan nasihat-nasihat baik kepada mereka.

Kepala madrasah memiliki peran yang sangat penting terhadap pendidikan di sekolah. Hal ini di buktikan oleh banyak riset penelitian di negara bagian Texas menemukan bahwa kepala madrasah memiliki dampak yang sangat besar terhadap prestasi siswa. ${ }^{13}$

Kepala madrasah mempunyai peran yang sangat penting dalam menjalankan aktivitas kegiatan pendidikan dan bertanggung jawab untuk memimpin proses pendidikan di madrasah terutama berkaitan membangun budaya akhlakul karimah yang ada pada masyarakat madrasah yang merupakan salah satu faktor penting. Upaya dalam membangun budaya akhlakulkarimah siswa dapat melalui optimalisasi peran kepala madrasah. Berdasarkan perspektif kebijakan pendidikan nasional terdapat tujuh peran utama kepala sekolah/ madrasah, yaitu sebagai edukator, manajer, administrator, supervisor, leader, pencipta iklim kerja, wirausahawan, dan sebagai layanan bimbingan dan konseling.

11 Ali Nurhadi, "Implementasi Manajemen Strategi Berbasis Pembiasaan Dalam Menumbuhkan Karakter Religius Siswa," Al- Afkar : Journal For Islamic Studies : Fakultas Tarbiyah. IAIN Madura 3, no. 1 (2020): 65-76.

12 Ali Maulida, "Metode Dan Evaluasi Pendidikan Akhlak Dalam Hadis Nabawi," Edukasi Islami: $\begin{array}{llllll}\text { Jurnal Pendidikan Islam } & \text { 4, }\end{array}$ http://jurnal.staialhidayahbogor.ac.id/index.php/ei/article/view/284/255.

13 Novianti Muspiroh, "Peran Kepala Sekolah Dalam Menciptakan Budaya Religius Siswa Studi Kasus Di Sekolah Dasar Negeri Grenjeng Kota Cirebon," JIEM (Journal of Islamic Education Management) 2, no. 2 (2018): 46, https://doi.org/10.24235/jiem.v2i2.3617. 
Kepala madrasah juga merupakan seseorang yang bisa menentukan keberhasilan dari madarasah tersebut, sebab kebijakan yang ada kebanyakan di buat oleh kepala madrasah dan akan di musyawarahkan bersama. Hal ini akan menenrukan keberhasilan suatu madrasah dalam jangka panjang.

\section{Faktor Pendukung dalam Pembudayaan Akhlakul Karimah Siswa di MAN Sampang}

Faktor pendukung merupakan penunjang dari terbentuknya program yang dilakukan di suatu lembaga pendidikan. Dimana dalam peningkatan budaya akhlakul karimah disini pasti ada yang namanya pendukung yang bisa mendorong suksesnya peningkatan budaya akhlakul karimah tersebut. Faktor pendukung dalam peningkatan budaya akhlakul karimah disini artinya faktor yang dapat menjadikan budaya akhlakul karimah yang di terapkan di suatu lembaga itu berhasil.

Dalam hal ini budaya akhlakul karimah di MAN Sampang, mengenai faktor pendukungnya yaitu ada 4 diantaranya seperti berikut ini.

Pertama kepala madrasah yang merupakan seorang pimpinan dari MAN Sampang ini memiliki peran yang sangat penting seperti halnya membuat kebijakan, memberikan contoh yang baik kepada bawahan dan siswanya sehingga kepala madrasah disini menjadi faktor pendukung terhadap peningkatan budaya akhlakul karimah itu sendiri.

Kedua guru merupakan seorang tenaga pendidik yang setiap harinya bertatap muka langsung dengan peserta didiknya sehinga guru disini menjadi panutan langsung setiap harinya. ${ }^{14}$ sifat dan sikap seorang guru akan ditiru oleh para siawa sehingga hal ini akhlak guru itu harus dijaga dengan baik sehingga hal ini akan menjadi salah satu penentu keberhasilan dari penanaman budaya akhlakul karimah itu sendiri.

Ketiga siswa itu sendiri. Siswa yang mempunya rasa ingin berubah serta ingin meningkatkan budaya akhlakul karimahnya maka ia akan berubah dengan sendirinya karen selain ada faktor motivasi eksternal juga ada faktor motivasi internalnya sehingga lebih mempermudah dalam peningkatan budaya akhlakul karimah disini.

Keempat lingkungan. Keadaan lingkungan disini juga menjadi penentu berhasilnya suatu usaha dalam meningkatkan budaya akhlakul karimah siswa di MAN Sampang, usaha ini akan berhasil apabila lingkungan di MAN Sampang ikut berpartisipasi, artinya semua masyarakat seperti teman dan termasuk adanya fasilitas yang lengkap akan menjadi faktor pendukung dalam keberhasilan usaha tersebut. Para siswa akan ikut serta dalam program tersebut jika fasilitasnya itu disediakan, maka dari itu lingkungan juga sangat berpengaruh. Di samping itu lingkungan juga sebagai salah satu faktor penentu keberhasilan belajar khususnya faktor eksternal. Lingkungan belajar yang kondusif dan mendukung dalam proses pembelajaran juga berpengaruh pada hasil belajar. Begitu juga dengan lingkungan yang mendukung dalam pembudayaan akhlakul karimah juga akan berpengaruh pada akhlakul karimah yang dibentuk.

14 Ali Nurhadi and Dedi Yusup, "Manajemen Pembelajaran Berbasis Pendekatan Perubahan Perilaku Dalam Meningkatkan Motivasi Belajar Siswa Di Smp Negeri 3 Pademawu Pamekasan," Re-JIEM (Research Journal of Islamic Education Management) 2, no. 2 (2019): 6, https://doi.org/10.19105/rejiem.v2i2.2871. 


\section{KESIMPULAN}

Berdasarkan pelaksanaan penelitian sesuai fokus dan tujuan dalam penelitian ini terdapat tiga kesimpulan seperti berikut ini.

Pertama bentuk pembudayaan akhlakul karimah siswa yang diterapkan di MAN Sampang adalah dimana setiap pagi sebagian guru dan BK menyambut para siswa yang datang, adapun siswa yang memasuki lingkungan MAN Sampang akan bersalaman dengan guru dan guru BK yang menunggu disana, senyum sapa dan salam dilakukan oleh para siswa yang langsung berpapasan baik itu dengan guru maupun sesama siswa. Bukan hanya itu saja ada beberapa budaya akhlakul karimah siswa yang diterapkan di MAN Sampang antara lain: tidak mendahului guru yang berjalan di depannya, tidak menaiki sepeda motor ketika akan lewat di depan guru dan lobby madrasah, membaca doa sebelum dan sesudah KBM.

Kedua kepemimpinan kepala madrasah dalam membudayakan akhlakul karimah siswa di MAN Sampang yaitu dalam pelaksanaan budaya religius di MAN Sampang peran kepala madrasah yaitu sangat dibutuhkan untuk terlaksananya budaya yang sedang dijalankan. Dimana dalam meningkatkan budaya akhlakul karimah siswa yang sudah diterapkan ini peran kepala madrasah sangatlah penting diantaranya yaitu kepala madrasah ikut serta dalam menjalankan kebijakan yang ada ,dengan adanya ini kepala madrasah sebagai pemimpin paling atas di MAN Sampang menjadi contoh tentang pembudayaan akhlak yang baik terhadap para guru dan siswanya

Ketiga faktor pendukung dalam pembudayaan akhlakul karimah siswa di MAN Sampang yaitu merupakan hal yang menunjang terlaksananya atau tidak dalam budaya akhlakul karimah siswa tersebut. Dalam hal ini faktor pendukung dalam pembudayaan akhlakul karimah siswa yaitu adanya sarpras yang memadai, kebijakan dari kepala madrasah, kemauan dari diri siswa itu sendiri dan sikap sifat tenaga pendidikan yang secara langsung bertemu dengan peserta didik akan menjadi tauladan bagi para siswa di MAN Sampang.

Berdasarkan kesimpulan tersebut sesuai manfaat penelitian diberikan saran khususnya kepada kepala madrasah dapat menerapkan kepemimpinannya dalam rangka membudayakan akhlakul karimah. Bagi guru perlu dukungan, kerja sama dan kekompakan untuk membudayakan akhlakul karimah bagi para siswanya.

\section{DAFTAR PUSTAKA}

Ali Nurhadi, and Dedi Yusup. "Manajemen Pembelajaran Berbasis Pendekatan Perubahan Perilaku Dalam Meningkatkan Motivasi Belajar Siswa Di Smp Negeri 3 Pademawu Pamekasan." Re-JIEM (Research Journal of Islamic Education Management) 2, no. 2 (2019): 288. https://doi.org/10.19105/re-jiem.v2i2.2871.

Alimin, Miftahul, and Muzammil Muzammil. "Keteladanan Guru Dalam Menanamkan Nilai-Nilai Keagamaan Sebagai Upaya Pembinaan Akhlakul Karimah Siswa." Edukais: Jurnal Pemikiran Keislaman 4, no. 1 (2020): 43-54. https://doi.org/10.36835/edukais.2020.4.1.43-54.

Bafadhol, Ibrahim. "Pendidikan Akhlak Dalam Persfektif Islam." Jurnal Edukasi Islami Jurnal Pendidikan Islam 06, no. 12 (2017): 45-61.

Helmawati. Meningkatkan Kinerja Kepala Sekolah/Madrasah Melalui Managerial Skills. Jakarta: PT Asdi Mahasatya, 2014.

Manik, Ester, and Kamal Bustomi. "Pengaruh Kepemimpinan Kepala Sekolah, Budaya 
Organisasi Dan Motivasi Kerja Terhadap Kinerja Guru Pada SMP Negeri 3 Rancaekek." Urnal Ekonomi, Bisnis \& Entrepreneurship 5, no. 2 (2011).

Maulida, Ali. "Metode Dan Evaluasi Pendidikan Akhlak Dalam Hadis Nabawi." Edukasi Islami: Jurnal Pendidikan Islam 4, no. 2 (2015): 855-69. http://jurnal.staialhidayahbogor.ac.id/index.php/ei/article/view/284/255.

Muspiroh, Novianti. "Peran Kepala Sekolah Dalam Menciptakan Budaya Religius Siswa Studi Kasus Di Sekolah Dasar Negeri Grenjeng Kota Cirebon.” JIEM (Journal of Islamic Education Management) 2, no. 2 (2018): 44. https://doi.org/10.24235/jiem.v2i2.3617.

Nivianty, Djafri. Manajemen Kepemimpinan Kepala Sekolah. Yogyakarta: CV Budi Utama, 2012.

Nurhadi, Ali. "Implementasi Manajemen Strategi Berbasis Pembiasaan Dalam Menumbuhkan Karakter Religius Siswa." Al-Afkar : Journal For Islamic Studies : Fakultas Tarbiyah. IAIN Madura 3, no. 1 (2020): 65-76.

Pamungkas, M. Imam. "Akhlak Muslim Modern: Membangun Karakter Generasi Bangsa." Marja, 2016, 140 pages.

Saefullah. Manajemen Pendidikan Islam. Bandung: CV. Pustaka Setia, 2019.

Sahlan, Asmaun. Mewujudkan Budaya Religius Di Sekolah Upaya Mengembangkan PAI Dari Teori Ke Aksi. Malang: UIN Maliki Press, 2010.

Solichin, Mohammad Muchlis. Akhlak Dan Tasawuf Dalam Wacana Kontenporer. Surabaya: CV Salsabila Putra Pratama, 2014. 